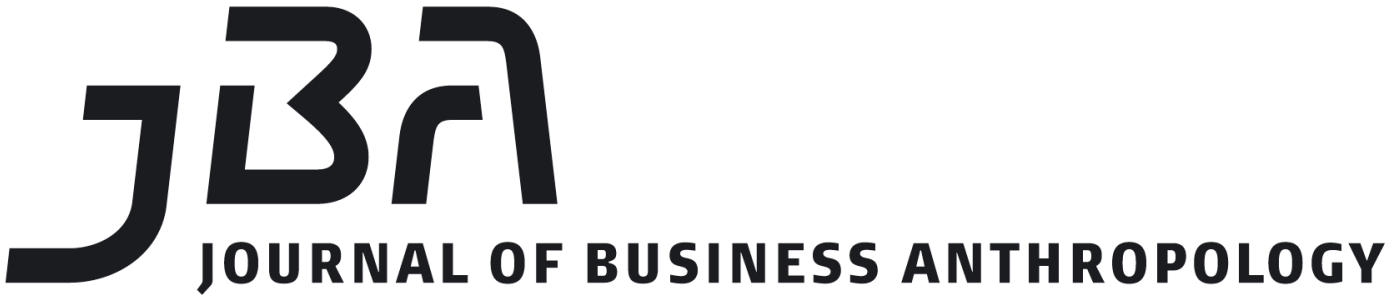

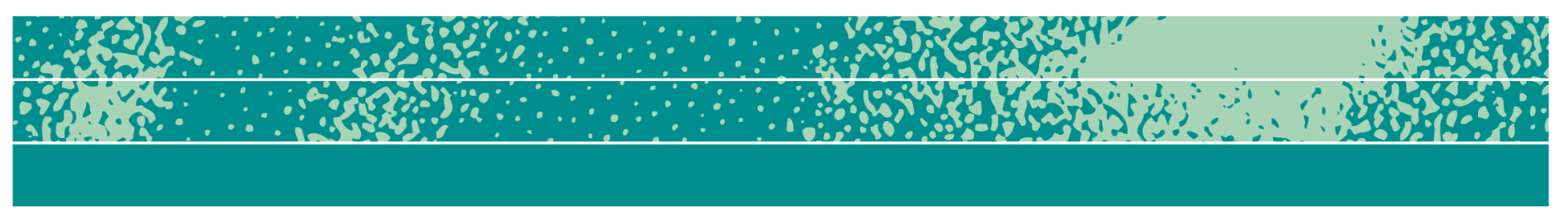

\section{Rebranding a South Los Angeles Corner Store: The Unique Logic of Retail Brands}

\author{
Hanna Garth \& Michael G. Powell
}

\begin{abstract}
Retail brands are important mediators of culture and value that help us understand contemporary consumption. Drawing on a collaborative ethnographic approach to a corner store-rebranding project in South Los Angeles, we demonstrate the ways in which physical retail spaces and their curated product mix can shape specific types of shopping experiences and behaviors. Building on recent studies of brand, we argue that retail curation is another important consideration for understanding how brand communications are formed, filtered and expressed.

Expanding on theorizations of brand we demonstrate how retail brands, as physical sites of experience, can attempt to influence relationships between consumption, identity and behavior.
\end{abstract}

\section{Keywords}

Brand, Shopping, Retail, Mediation, Food Desert
Page 1 of 24

JBA 6(2): 175-198

Autumn 2017

(C) The Author(s) 2017

ISSN 2245-4217

www.cbs.dk/jba 
On Saturday March 29, 2014, another sunny morning in South Los Angeles, a crowd of over 200 people shut down streets for a block party to celebrate the grand re-opening of "Alba Snacks \& Services." Previously called “\$1 Dollar Warehouse," this retail rebrand was recognized as a "corner store conversion" project, intended to address a lack of access to healthy food in lower-income urban communities, a problem frequently framed and labeled as a "food desert" issue. ${ }^{1}$ The rebrand strategy hoped to change consumers' perceptions of the store's format from a corner store, into a unique yet recognizable medium. Community leaders heralded Alba as a model for potentially alleviating rampant health problems. The rebranding relied heavily on a brand strategy to guide the organization, selection, and novel combination of product brands in one destination and manage the presentation in a newly designed environment. This project reveals a potential for the retail brand form to uniquely shape consumer culture and perform the role of a cultural mediator.

Brands and branding have become a topic of conversation and critical discourse in cultural anthropology and other fields over the last couple decades. Because branding has become ubiquitous in the shaping and production of contemporary social forms-from how party politics operate as brands, to the rapid growth of mass social movements like Occupy, as well as a broader range of consumer products like Coca-Cola and retail destinations like Whole Foods-understanding the dynamic structure and potential for how branding functions and the strategic work underlying the brand has never been more important to the arsenal of intellectual tools wielded by cultural analysts (see Agha 2015; BanetWeiser 2012, Bear et al 2015, Allison 2009, Bratich 2011, Dent 2012). Asif Agha's (2015) recent work on brand formulations shows the importance of the reanalysis of brand, as brands are taken up in new and different social practices and contexts. This article, focused on and building on critical analyses of brand in the field of cultural anthropology, details the ways retail brands and brand strategies function, pluralizes the notion of brand, and problematizes some critiques of brands.

We define "retail brand" as a conceptual project-whether located in a physical space or online, but always also a site for cultural imagination - that seeks to guide shoppers toward the sale of a particular combination of goods for use, consumption, or gifting. Retail brands use practices of curation, deliberately selecting specific items for offer,

\footnotetext{
${ }^{1}$ We use the term food desert critically. Although this area is continually labeled as a food desert, or area lacking healthy food, such as fresh fruits and vegetables, we know from experiences there that the area has many street vendors selling fresh fruits, small stores selling limited produce, and even larger grocery stores offering a wide variety of healthy foods. For further discussion of the problems of stereotypical and vilifying urban communities of color see Kelley (1997) and Taylor (2016).
} 
excluding others and combining or juxtaposing products in unique ways, as a core strategy for creating value. They employ design to further develop their brand strategies in immersive experiences. In doing so, retail spaces represent a material framework that seeks to mediate the social practice of shopping, simultaneously allowing and restricting decision-making practices that have direct impact on consumption activities. The retail space, considered as a medium for cultural communication, is paradoxically both influential and yet easily taken for granted.

The focus of this article is on the cultural production of a retail brand and the retail branding process, rather than a study of shopper receptions to retail environments. If cultural production happens through a process of identification and contextualization (cf. O'Connor 2003), then the project of retail branding closely mirrors this process, by seeking to have shoppers identify with the brand's decision-making practices in selecting products, and designing environments that immerse shoppers into a contextual reality. While other forms of brand are involved in cultural production, the retail brand plays a dual role as a cultural producer and mediator, with unique opportunities to shape habits and expectations of consumerism.

This ethnographic investigation of an evolving retail brand strategy also illuminates a broader set of questions. In a context of often overwhelming flows of information, products and ideas available to so many today, how do people develop strategies to help navigate, negotiate, make sense of and make decisions about these options? So many people and organizations-including for profit and not for profit interests, public and private entities, corporations, governments and NGOs-are all producing more and more "stuff" for consumption. How does a person process this? Retail brands "help" us make sense of particular sectors, here the food world, and may subtly guide decision-making. They cannot be treated as neutral, natural or innocent points of access. They may shape subjects and influence decision-making. As such, they produce culture and represent a powerful way that organizational policy or business strategies may influence broad audiences of people. The process of creating and implementing brand and retail strategy can be recognized as a way of understanding how business-related activities attempt to influence and change our lives. Following Hannah Appel (2015) we focus on the creation and implementation of a business strategy, here to produce a corner store conversion, with the potential capacity for future cultural production (see also Bear, Ho, Tsing, and Yanagisako 2015).

Ethnographic research on the Alba conversion process was carried out by a two-person collaborative team, which combined the expertise of two cultural anthropologists with different but overlapping backgrounds and professional experiences. Since 2010, Hanna Garth, a cultural and medical anthropologist, has been studying the food justice 
movement in Los Angeles. Michael Powell, a cultural anthropologist and professional brand strategist, has been studying brands and working for a strategy and design firm in Los Angeles since 2007. The Alba rebrand was Powell's first non-profit intervention project, which he began work on in $2012^{2}$. Garth carried out ethnographic research on the rebrand project as part of a larger study of food justice interventions in South LA. Both authors engaged in ethnographic work at the physical store location, and via engagement with the many emails, phone calls, and meetings it took to complete the project, and we continue to track the ongoing evolution of the Alba store within the larger Los Angeles Food Justice movement.

\section{Locating Retail Brands}

In recent years, many anthropologists have begun to examine brands and branding (cf. Agha 2015; Foster 2007; Graan 2013; Luvaas 2013; Mazzarella 2003; Nakassis 2012, 2013; Shankar 2012; Thomas 2013; Weiss 2012, Lury 2004, 2010). Research on brands demonstrates a potential to illuminate our understanding of how contemporary political economics impact the everyday lives of consumers. While much of the work on branding revolves around semiotics, anthropologists have also studied brand as a mechanism for negotiating relationships between corporations and consumers, as well as legal regimes of intellectual property (Moore 2003). ${ }^{3}$

As Nakassis (2013) outlines, branding originally stemmed from attempts to differentiate commodity forms within industrial capitalism. However, as societies shift from industrial capitalism to neoliberalism, brands and the ways their meanings are taken up have also shifted (Nakassis 2013; cf. Fortun 2012). In neoliberal settings, brands have been separated from physical commodities and manufacturing. At the same

${ }^{2}$ Our methods involved in-depth interviewing and participant-observation. Garth and Powell together interviewed those involved in the store conversion, while Garth also conducted a series of interviews with Powell about Alba and branding more generally. They tracked news and social media about the store, documented the grand re-opening event, and have done participant-observation research at follow-up events. Powell's experience has brought him inside the world of food retail brands and consumer packaged goods, while Garth's comparative distance from branding processes created a productive tension to generate insights found here. The blurred lines of ethnographer and interlocutor gave rise to unique forms of collaborative knowledge production. (See also Garth and Powell 2013).

${ }^{3}$ Recent work in the emerging interdisciplinary field of "Consumer Culture Theory" (CCT) similarly engages with the question of brand and the process of branding (Cayla and Eckhardt 2008), the creation of brand communities (Holt 2004, 2012) and branded environments (Diamond et al 2009). The CCT literature has been centrally focused on marketing and consumer research audiences, in journals such as Journal of Consumer Research, the Journal of Marketing, and the Journal of Marketing Research, to name just a few. For a more thorough overview of CCT and its potential relationship to anthropology, see Joy \& Li (2012). 
time, anthropologists have shared a critical perspective first articulated by popular social critics, such as Naomi Klein, who argue that brands are more interested in producing culture-namely the persuasive force of culture-than producing products or commodities that people really want or need. That is, branding allows for a profit-driven division between production and marketing (cf. Banet-Weiser 2012). The brandfocused corporation, which attempts "to free itself from the corporeal world of commodities, manufacturing and products" now seeks "to exist on another plane" of "corporate transcendence" (Klein 2000: 21-22).

While brands play a central role across the globe, as Manning (2010) argues, there is no agreed upon definition of brand, or how to distinguish between categories of brands. Previous studies have grappled with the murkiness of branding in terms of how brands are produced, managed, and understood by consumers (Caldwell 2004; Klumbtye 2010; Luvaas 2010, 2013; Manning and Uplisashvili 2007; Thomas 2013, 2014; Vann 2006). Perhaps due to the slipperiness of brand, and the global scale of circulation, most studies have focused on how brand images and message are produced and managed, especially through advertising.

Recent cultural anthropology scholarship has attended to wellknown product brands as commodities, such as Mazzarella (2003) on various product brands in India, Thomas (2013) on counterfeit clothing product brands in Guatemala, or Foster (2007) on Coca-Cola worldwide. These works focus on aspects of brand more controllable by producers, lawyers and professional branding or marketing agencies, such as logos, visual identity systems, product packaging, advertising, communications, and quality control. This scholarship illuminates a valuable sense of how commodities are caught up in processes of cultural production and reception, within and beyond the reach of intellectual property law.

However, this existing literature has offered little analysis of an important distinction and relationship between product brands and other forms of brand, such as brands that mediate other brands. This includes a wide range of brands, from technology brands like Facebook or Google that use algorithms to organize content, to more traditional media brands and magazines with human editors. Our focus in this essay is on retail brands, which are crucial intermediaries or mediums for organizing products for sale. Some of these retail brands, such as Walmart, are powerful global corporations, but the vast majority of retail spaces worldwide exist on a broad continuum, from formal establishments to informal temporary spaces. The border between the retail brand and a mere retail space is ambiguous and indistinct. Further, many retail brands are currently evolving their mediating relationship with product brands, and with consumers.

The retail space and the retail brand are often elided in a chain that connects product brands to consumers. Retail spaces and retail 
brands are currently treated as an invisible everyday practice or a mere access point for acquiring products. For example, while Daniel Miller $(1998,2001)$ has analyzed a "theory of shopping," this analysis overlooks the distinctiveness and heterogeneous landscape of retail brands.

However, recent work illuminating the product brand through the lens of the counterfeit may help us think about how retail brands operate. Thomas, Nakassis, and others (Boellstorff 2003, Luvaas 2013, Vann 2006) have explored the spaces and semiotic excess between products and their brands, which allow for new cultural practices not anticipated or manageable by these powerful product brand owners. This includes the creation of counterfeit or appropriated brands and the novel mixing and matching of clothing styles. These insights illuminate the situatedness of the retail brand in a product brand's commodity chain, which flows roughly from the producer/maker, through marketing/advertising and then to the consumer, through consumption practices. We might similarly ask how retail brands, as a medium for consumerism, may recontextualize brands as products pass through the commodity chain. In doing so, the retail medium may emerge as a powerful mediator, potentially shaping shopping behaviors and influencing consumer culture, as well as negotiating relationships between local communities and globalized corporate and legal structures. While the value of the retail brand does not supplant that of the product brand, the relationship between these two types of brands has the potential to transform the value of each. The retail brand therefore warrants further attention.

\section{From Corner Store Conversion, To Re-Branding Strategy}

Over two years before the Alba Snacks \& Services grand re-opening, Clare Fox, then of the Los Angeles Community Redevelopment Agency (CRA/LA), first set foot inside the $\$ 1$ Warehouse store. ${ }^{4}$ The store is located on Vermont Avenue, in South Los Angeles, a busy urban thoroughfare filled with a mix of small local retailers, fast food restaurants, corner stores and liquor stores. Just north of the site is a junior high school, and a high school is several blocks east. The $\$ 1$ Warehouse is located in a relatively new strip mall structure, sharing a parking lot with a donut shop, a self-service laundromat and a cell phone store, among other retailers. The building was constructed in 1993, after the prior retail strip mall on the site burned down during the uprising of 1992, which originated less than a mile away. ${ }^{5}$ During the 1992 uprising,

\footnotetext{
${ }^{4}$ Research participants have acknowledged and allowed the authors to use their real names in this essay, due to the public nature of the project, which has been reported on in the news media.

${ }^{5}$ We use the word uprising to refer to what is commonly called the Los Angeles riots as a way of destabilizing the racialized narrative power of many media sources. See Redmond and Soyjoyner (2015) on the importance of using anti-
} 
many retail spaces up and down Vermont Avenue were looted and razed, and retail spaces were targeted at a much higher frequency than other surrounding buildings. The rebuilding of South LA retail space was a slow process with little attention to socially conscious design. In the mid2000s, CRA/LA began an initiative to rebuild some South LA stores with grants for façade improvement only.

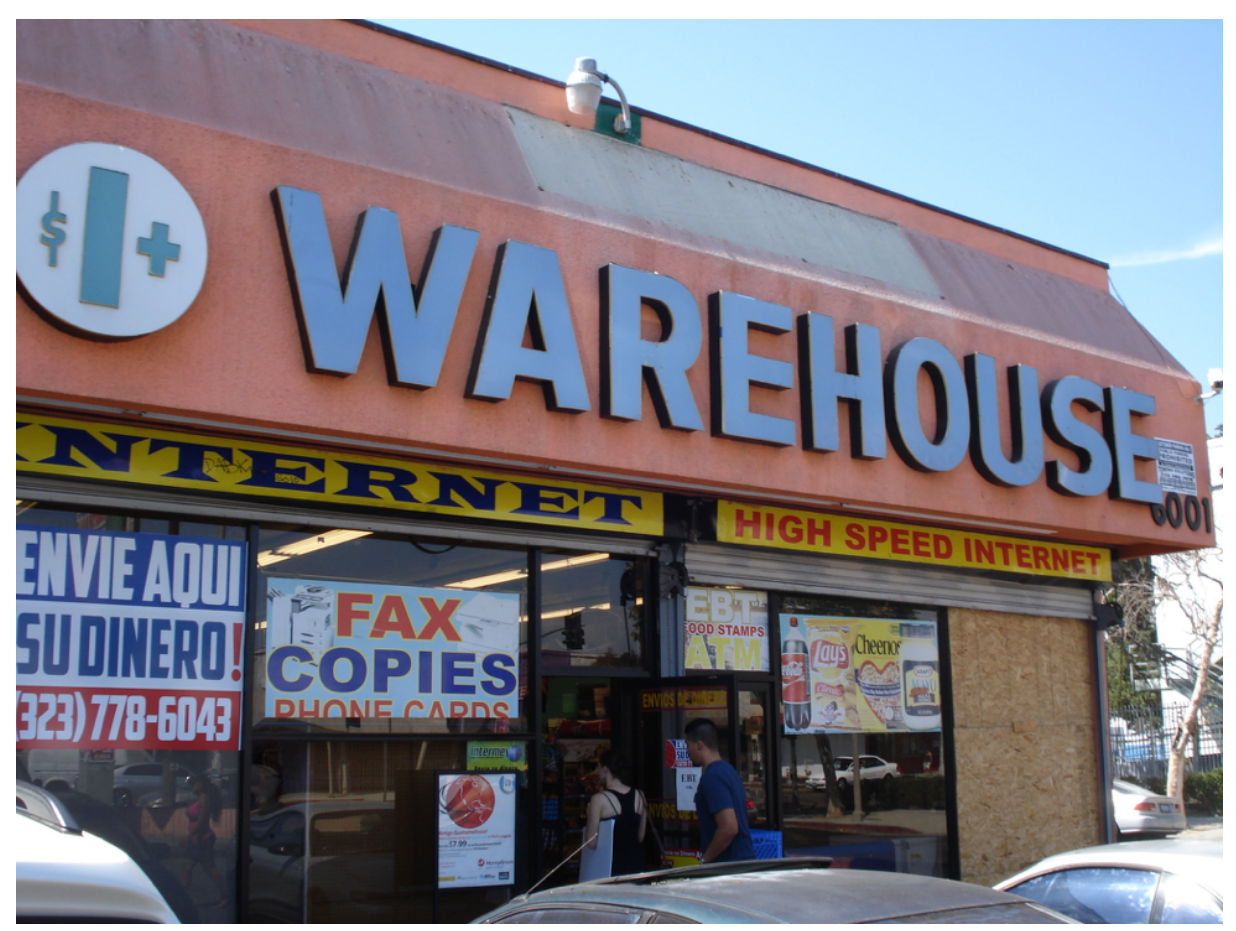

Figure 1: Exterior Dollar Warehouse Photo by Michael Powell

On this first visit, Fox presented Nelson Garcia, the store's owner and operator, with an opportunity to participate in a corner store conversion program. CRA would offer financial assistance to Garcia if he would provide shoppers access to fresh produce. Similar corner store conversion programs undertaken throughout the United States by food justice advocates put forth the basic equation for this project: space would be carved out in some part of the store to offer fruits and vegetables. These projects consistently stress the need to provide "access" to fresh produce, as a solution to the food desert's dearth of grocery stores. However, these approaches and the discourse of access fail to address the dynamic experience of a retail space, or the retail brand's potential to shape and mediate consumers' relationship to shopping and eating habits. These "healthy" living solutions also often stigmatize "junk" food, with an unclear amount of uptake from the communities where programs exist (Jung and Newman 2014). 


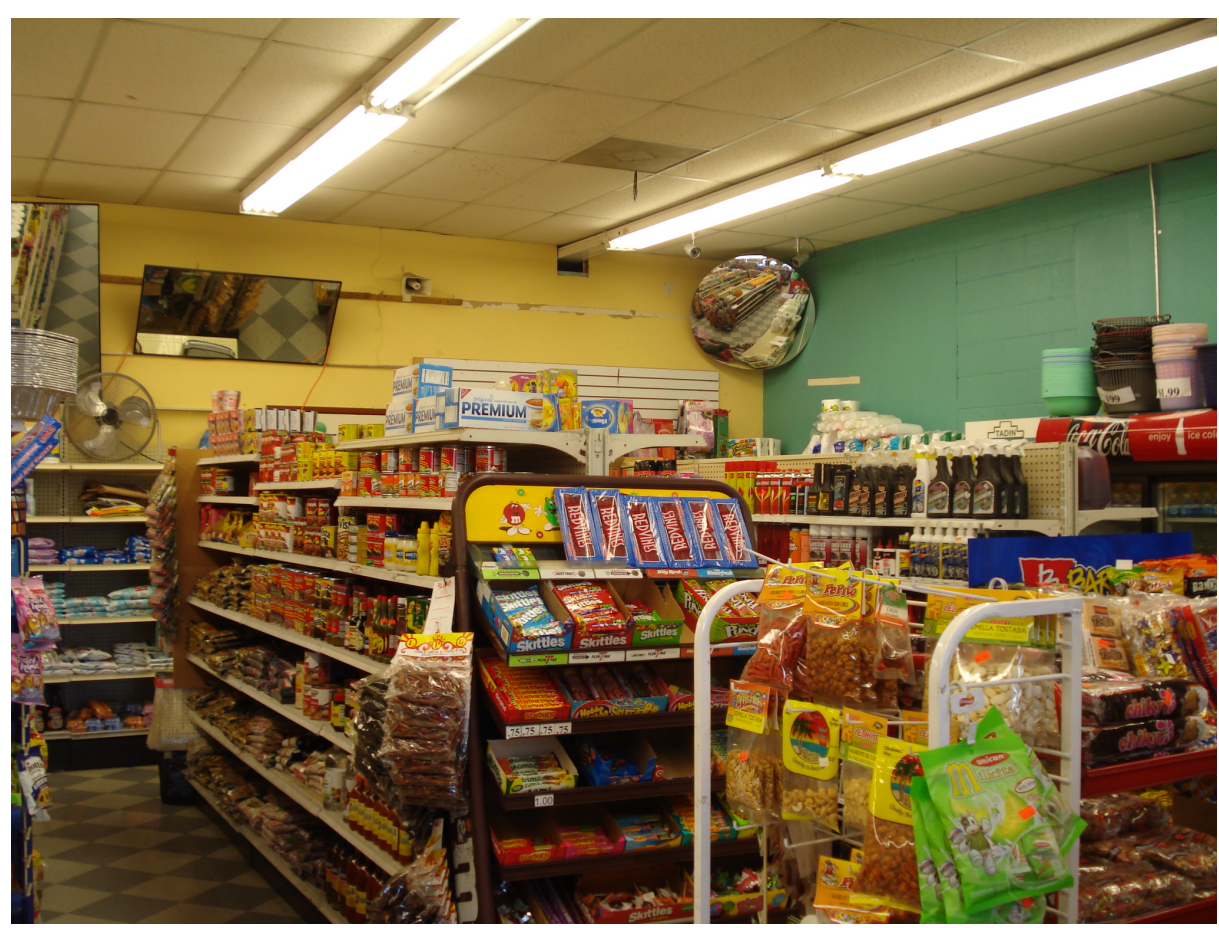

Figure 2: Interior Before Photo by Michael Powell

Garcia, open-minded but pragmatic, was cautiously optimistic about the store conversion proposal. In his mid-forties, he had experience in food retail-working at 7-Eleven convenience stores and prior to that, alongside experienced fellow Guatemalan immigrant grocers in Long Beach. While he considered selling fresh produce provocative, he worried about the financial risks involved in selling produce, which requires rapid product turnover and proper "presentation":

When Clare [Fox] came and she talked to me about the business conversions to be able to put in an area for selling fruits and vegetables to have more options for sale, I liked the idea. But the idea - if I was going to add fruits and vegetables - it would require an investment on my part. This part was hard to me - to want to sell fruits and vegetables - because I didn't have [money] for the investment, that would be number one. And second is the act of just buying some boxes of fruits and vegetables and putting them in some corner on the floor, [this] was not going to work well. I needed to find a place to put them, have a better way to present them. Not just to put some boxes there, but to have something visible that people can feel comfortable [with] and can see.

Garcia recognized the consequence of a new product category in his small store, which would displace other products and create a chain reaction of disruptions. As he explained, "we had to arrange a section [for produce], and to arrange a section meant that we had to arrange the rest for the project" in tight confines.

Garcia's insight is typical among experienced retailers who use their store environment to shape communications: fresh produce signals 
freshness and quality. He subtly critiqued examples of corner store conversions projects led by policymakers, food justice advocates and community organizers.

Garth: Where did you get the idea that to have fruit and vegetables it would be in a box on the floor?

Garcia: [They] showed me a picture where they had put something similar in another place [another store]. And for me it was not going to work well like that. For me - someone gave me some advice: two people can see the same product but [the products] are going to have different success because the key is in how the product is presented.

Garth: Who taught you this?

Garcia: Oooo, many years ago.

Several months after the partnership began, the project took a new direction prompted by a new team member, Michael Powell, who Fox had previously recruited to help with a corner store operator training program. If Fox represented the corner store conversion perspective, and Garcia the practical retailer's perspective, Powell represented a professional retail design perspective rooted in corporate brand strategy. Following a doctorate in cultural anthropology, he had nearly a decade of experience developing brands and their retail experiences around the United States, working for supermarkets, convenience store chains and consumer packaged goods companies. In addition to consulting, Powell also had a network of experienced retail designers who could take a project from concept through construction. His team offered pro bono services.

Through in-depth interviews with Garcia, Fox and other team partners, as well as store observations at the $\$ 1$ Warehouse and other retailers in the area, Powell and the design team helped craft a new retail brand strategy for Garcia. The group explored the store's product inventory, competitive marketplace, and current customer audience. Despite being located in a "food desert," competition in the area included other corner stores, fast food chains and small and large grocery chains. Based on Garcia's insights, Powell recognized that the $\$ 1$ Warehouse was closely affiliated with the same expectations associated with other corner stores in the area: a destination for "unhealthy" snacks, "junk" food, and sugary drinks. Garcia explained how customers used the $\$ 1$ Warehouse as they would any other corner store, stopping by frequently over the course of the week, typically before or after work, buying just two or three snack products and spending less than five minutes in the store.

Observations of the existing store environment reinforced these insights. While the store had no formal product categories to organize its space, shoppers mostly encountered salty snacks, candy and carbonated 
soft drinks upon entry. On the left side of the interior, a clear plexiglass barrier surrounded a cashier's station, where remittance services were housed and a wall of international telephone cards served as a backdrop. The rear of the space consisted of three aisles and a back wall of product, with one dead-end aisle on the left side dedicated to an "internet café." The shelves had a range of miscellaneous products without clear categorization: cleaning supplies next to pet foods, canned foods next to beauty supplies. For the most part, shoppers spent their brief trips in the front half of the store, grabbing candy and snacks, then heading to the cashier before leaving. The rear aisles and internet café were underutilized, and many products noticeably collected dust.

The retail rebrand strategy focused on re-envisioning the store's target audience, shopping occasion and product mix, as well as providing a narrative suggesting how the environment might better target specific shopping behaviors, occasions and decisions. Garcia described it as "vision" work:

So we realized that this was not just about going to the market and buying fruits and vegetables, but that we needed minds that had this understanding and could support us with these ideas so that the project could come to life. So that was how I came to know Michael [Powell] and other people, and how this project was made possible...We were in a stage when we didn't have a vision, we didn't know how to get to another level, we didn't know how, I wanted to do it but I didn't know how.

The new "level" described by Garcia reflects the role of the strategy in guiding the project to "come to life." The retail brand would now focus on offering healthier snacking products to the store's existing customer base, because those people already visited frequently and used the store as a snack destination. While previous corner store conversion projects inserted a generalized fresh produce department into open spaces inside of existing store layouts-asking snack shoppers to consider healthy meals and eating-Garcia's store would focus on healthier packaged snacks and fresh produce considered a "snack." For example, bananas, immediately consumable by a single person without preparation, would be featured, but zucchini, requiring preparation, would be omitted. Further details, including the brand's new name, graphic identity, product mix, and even the store's flow and layout, would align with the snack-focused strategy. Even employee's attitudes and service level could be subsumed within this larger vision.

In developing this strategy, the group tacitly agreed to use the brand as a conceptual device to negotiate the political interests, economic pursuits, and social policy agendas of the groups involved. The CRA, and later the LA Food Policy Council, sought to push a food justice agenda, introducing healthier products into the neighborhood. Garcia wanted to 
insure financial reliability, create potential future growth, and promote a healthier community. With this strategy, Garcia could continue to provide snacks to his existing customer base. The strategy also allowed Powell to use experience consulting for larger clients to contribute to a "social cause," and positively impact the wellbeing of this urban community. Further, the brand sought to mediate consumers' relationships to their food, accepting their snacking habits while also seeking to subtly constrain and re-orient shoppers towards healthier snack product options.

The $\$ 1$ Warehouse rebrand project represents an attempt to give shape to a retailer, in order to achieve specific goals that target specific shopping behaviors and consumption habits. As Celia Lury describes the emergence of the product brand in conflict with retailers in the late $19^{\text {th }}$ century, "The development of the corporate and product personalities was in part an attempt to replace the role of the retailer, the individual that had provided continuity and a trustworthy context for the consumer" (Lury 2010). As such, the rebrand project represents an assertion by the retail intermediary to reassert its relationship with consumers.

\section{Designing the Floor}

While a new product focus could have constituted a retail rebrand for Garcia, the rebrand team also redesigned the store environment to manifest the brand through physical experience. The production of space demonstrates how retail brands attempt to shape the bodily experiences and perceptions of shoppers, thereby mediating relationships to product brands and attempting to influence shopping. This points to the ways cultural production can happen through the design process (cf. Murphy 2013). More specifically, the design of space reinforces the ways retail brands can generate value through curatorial practices. By curate, we refer to the process of selecting which products to offer or not offer, as well as consolidating products into distinct categories that shape the shopping experience and juxtaposing products that can suggest product selection combinations. At times, retail brands that actively curate their product offering can circumvent or challenge the intent, purpose and strategy of the product brands they offer for sale. Acts of curation, when combined with physical design constraints, may actually thwart product brand projects actively seeking to influence retail spaces.

The Healthy Snacking Zone consisted of design elements requiring minimal construction. Existing grocery "gondola" shelves were painted red to distinguish them from the rest of the store. Wooden endcaps were created, modified from inexpensively purchased Ikea furniture, to merchandise products on natural wood backgrounds. Guatemalan fabrics were sourced to serve as backdrops for wooden endcap displays. Signage plans were minimized to a hanging "SuperSnacks" sign with a zig-zag 
green pattern background. Only healthier snacks - such as trail mix, nuts, and fresh fruit - were allowed in this zone, which meant excluding top selling items from prime store real estate. Finally, a small cooler for refrigerated snacks - such as yogurt, hummus, and fresh fruit - was integrated into the zone.

Through design, the team created a "threshold," marking the experience of the snack zone and communicating a distinction between healthier snacks and all other products. The intention was to make this zone feel special and valuable, in the hopes shoppers would pause, linger, or even reflect on these products.

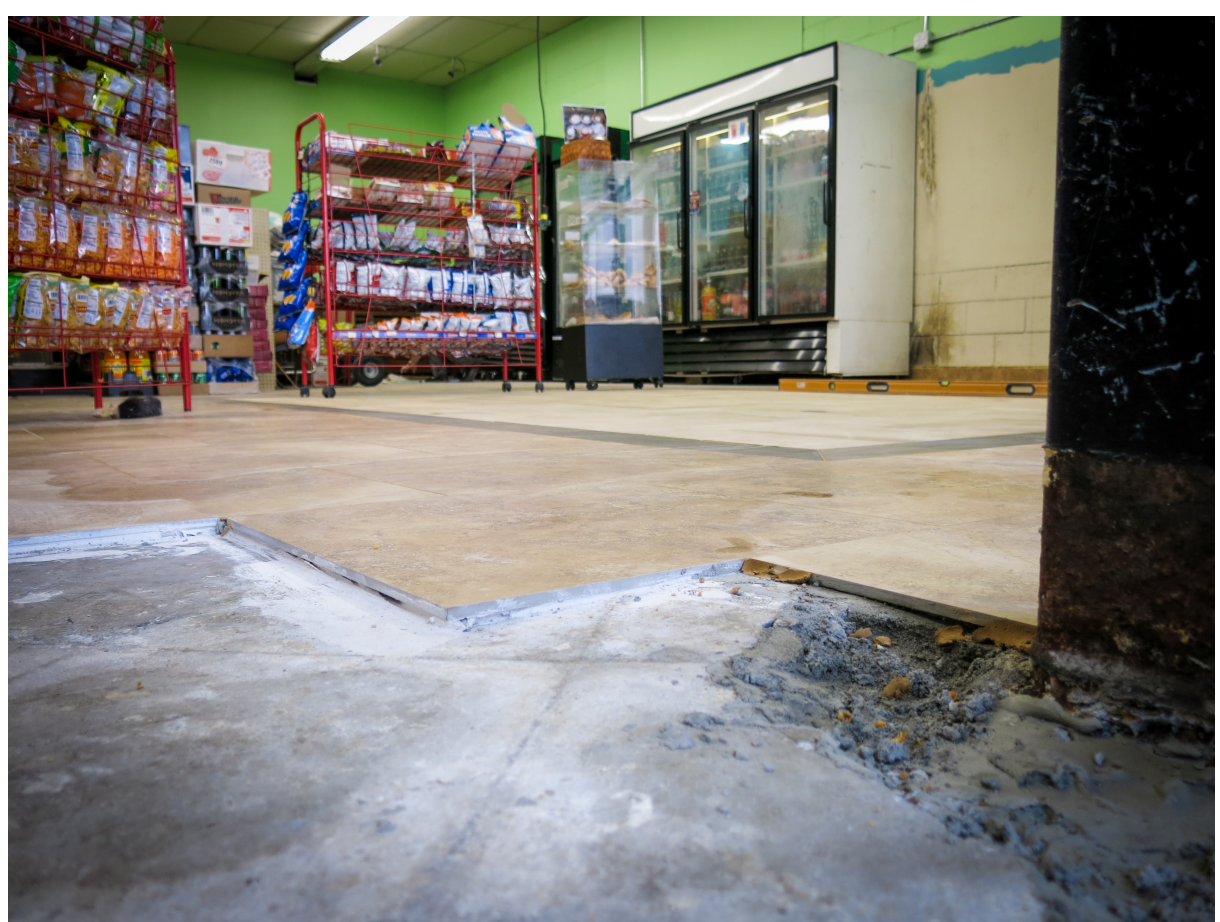

Figure 3: The Floor Photo by Rudy Espinoza

Design plans called for new flooring for the zone, while the rest of the store's existing tile would remain, in order to save money. Garcia then changed plans and decided to purchase flooring for the entire store.

Although initially enthusiastic, the design team became concerned when they saw the flooring options under consideration. While the designers suggested grey tones to contrast the natural brown tones of the snack zone, Garcia chose differently. Fox explained to the design team in an email:

Nelson [Garcia] reviewed your comments and we debriefed just now. He found a cafe colored tile that he really likes (he likes the natural, earth-like tones in relation to the blue and green of the walls) and prefers that over the grey. He agrees with the woodlike ceramic tile concept for the snacking zone. 
The tile's quality was suitable for retail usage and matched the store's environment. But the design team felt some of the Healthy Snacking Zone's potency was lost. Others, including Garth were initially puzzled by the designer's passion. The flooring choice was tasteful and pleasant for a food environment. However, from a brand strategy perspective, a more pleasant overall experience diminished Alba's key message: healthy snacking. For designers, the goal was not to create a subjectively pleasing experience. Rather, they used the design of space as a form of experiential communication. They sought to intervene and disrupt expectations of the traditional corner store's shopping experience. And they used the brand strategy to resolve ostensibly aesthetic or personal matters of color choices. This branded approach to space forces actors to become aware of their surroundings, and may undermine perceived naturalized production of taste as described by Bourdieu (1984). The designer Milton Glaser similarly noted the value of flooring in supermarkets as a sign retailers might use to signal a discount price point or some other reference (1985).

Through design, the Healthy Snacking Zone allows the brand to assert its role as a mediator. Instead of the "blank canvas" approach employed by the $\$ 1$ Warehouse, with a homogeneous retail floor indifferent or open to external influence, the redesign structured the store experience. The influence of the $\$ 1$ Warehouse store experience was easily taken for granted, but the Alba redesign was a more overt and perhaps reflexive message to the shopper. As a communication medium, the spatial experience of the store represents a material framework that constrains and facilitates social practices-here, the act of shopping for snack foods. In doing so, the store space, as communication medium, acts as a material representation suggesting how one should eat, though the choice is ultimately left to the shopper.

At the same time the design sought to influence shopping practices, it also facilitated and placed limits on business practices. For instance, once or twice a week, a representative from at least one global consumer packaged goods (CPG) company would visit the store and directly stock products on the shelf for Garcia, including globally recognized products. These extra services were free of charge, though Garcia paid for the products. The CPG representative would often also directly install signage, promotional displays, and even merchandising fixtures. As a result of the redesign, CPG representatives were limited to stocking products in rear aisles of the store and promotional signage opportunities were greatly diminished because they did not fit the brand's graphic identity. Representatives' initial attempts to stock their healthier products in the prominent Healthy Snacking Zone were rebuffed. As a result, Garcia may have sacrificed profits from the sale of these products, though they were still available, just less visible. The retail brand attempted to assert its role as a voice for healthier snacks, 
effectively renegotiating Garcia's relationship with these globally powerful product brands.

In this role, retail brands are not only or simply, as in the past, guarantors of quality, in part because product brands have assumed that responsibility. Instead, many retail brands have explicitly taken on a curator's role: a content specialist selecting and distinguishing cultural products within a large catalog of potential product choices available today. One example of the brand as curator is Whole Foods Market, not just in the way this supermarket brings together natural and organic product brands, but also in what they refuse to offer. For instance, Whole Foods does not sell Diet Coke, even though they could generate enormous revenues from it. The Whole Foods retail brand excludes the product brand, arguing that Diet Coke does not meet their standard. Indeed, carrying Coca-Cola products may damage the brand that they have worked so hard to establish.

Curatorial activities among brands may, to borrow Lury's (2010) phrase, re-intermediate the retailer between product brands and consumers. The retailer may alter the larger terrain of brand relationships and impact shopping practices. First, the retail brand decides which products to carry and not carry. Second, many retail brands may attempt to combine product brands together in unexpected or unanticipated ways. And third, retail brands send messages to shoppers about their editing philosophy within an immersive environment.

By recognizing the curatorial capacities of retail brands, we also recognize retail as flexible and changing over time. In the case of Alba, the rebrand process set the foundation for a new pathway, but not a rigid structure. Unlike the narrative of brands developed by corporate entities and then pushed on local outlets around the globe, the Alba brand was developed in collaboration and conversation with Garcia. Moving forward, Garcia and any Alba partners must actively take up the role of curator, constantly deciding "what's right" for the store to sell, based on a flexible set of principles, which include healthy snacking, as well as profitability. In one follow-up site visit, for example, packaged snacks that were arguably "unhealthy" had gravitated into the Healthy Snacking Zone, as Garcia considered different ways to produce the zone. Retail space is remade sometimes daily or hourly, and is constantly in flux, much the same way curators must constantly develop and hang new shows for their galleries.

Arguably then, the retail brand's role poses a provocative question, with important implications for design: In a situation where the vast and expanding catalog of product brands outstrips the physical limitations of a retail space, could the practice of curation be considered as valuable as products themselves? In the past, when retailers failed to carry a product 
brand, it was considered a liability or a negative value. Today, deliberately excluding a product brand or purposely juxtaposing product brands to inspire consumer solutions (e.g. snacking occasions or meal solutions) may be part of a brand's core strategy for creating value, by helping shoppers make sense of things. The design of a retail brand's experience can embody this value. Design acknowledges the physical limitations of space, and may find ways to use those limitations to benefit and even accentuate the purpose of the retail brand.

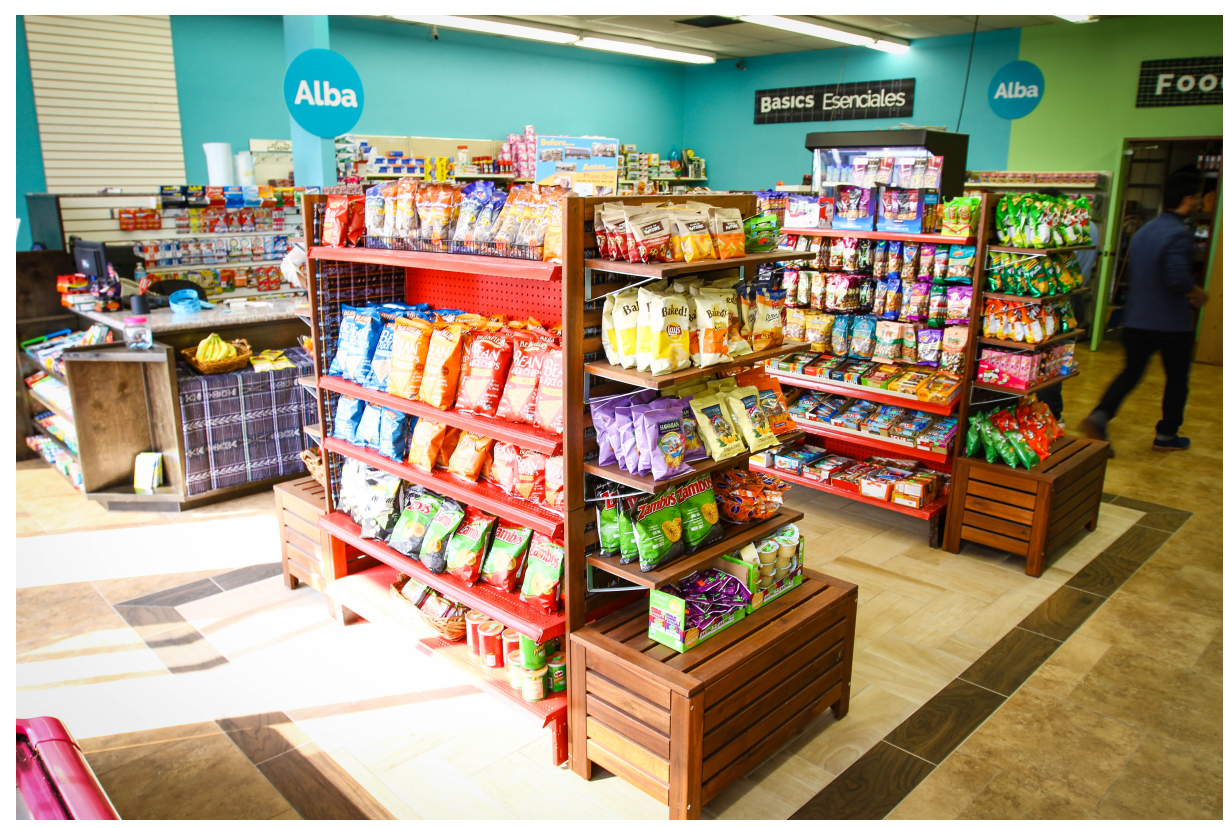

Figure 4: Healthy Snack Zone after Conversion Photo by Rudy Espinoza

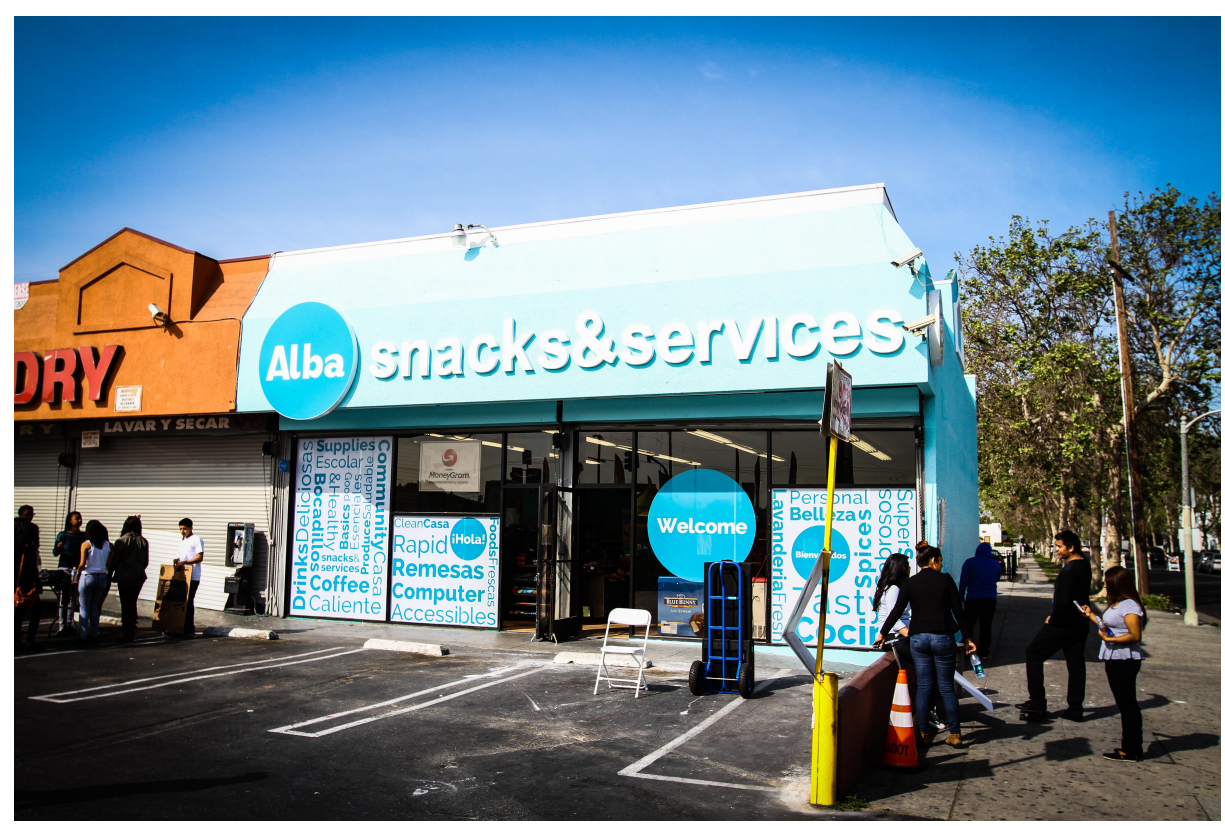

Figure 5: Alba after Conversion Photo by Rudy Espinoza 


\section{What Is Branded?}

From the outset of the rebrand project, everyone on the team agreed the existing brand name "\$1 Warehouse" had no weight or memorability. Exterior signage lacked presence, and few customers could recall the name, according to Garcia and others. Students who lived and studied in the area could not recall the corner store's name, even after shopping there many times. Garcia did not care about or like the name, which he inherited from the store's former owner. Nor did Garcia own any legal rights to the name. Moreover, the name was simply untrue. Neither a dollar store, nor a warehouse store, $\$ 1$ Warehouse attempted to index categories of retail format that did not match anyone's expectations of the store experience. Garcia did not use the name to shape his product offering, which might have entailed selling products for $\$ 1$.

If a brand's name and logo is typically associated with the branding process (i.e. the imagined act of indelibly stamping some product or service), then in considering the retail brand, and mediation brands more generally, what exactly is being "branded" here? On one obvious level, the store itself is branded-the facility, space, collection of products, operations, supply chain infrastructure and customer services offered. And by extension, if we follow the logic of contemporary branding, we might employ Pine and Gilmore's (1999) formula that the experience and its emotional dimension, personality attributes and symbolic associations are branded alongside the tangible physical location through association (Moore 2003). But by looking at the retail brand as a mediating form, we might instead consider the process or mode of curation as what is being branded. In turn, retailers may brand a style of shopping or the decision-making acts happening.

Retailer brand names tend towards the literal and functional, as opposed to the more emotional and symbolic names used by product brands, such as Nike, Apple or even Oreo. Generally, retail brands, especially in the food retail sector, tend to further reinforce their intermediary role and/or communicate their curatorial role. To create a new brand name, the Alba rebrand team reflected on the new brand strategy, and sought ways to distinguish the store from other corner stores, which could similarly lay claim to being a snacking destination. Instead, the team sought to imagine connections between the curation of the healthy snacking category and some source of unique community identity or Garcia's identity that might lend credibility, meaning or dimension. In this sense, the team was well aware of their role in the cultural production of this new retail brand, and sought to co-create value with their consumer base (see Arvidsson 2006, Foster 2007). The naming process was less focused on invention, and more focused on how to channel cultural meanings from elsewhere, placing the brand at an intersection. 
Garcia showed interest in crafting a brand that customers could understand and relate to, and that could build a more loyal following in a sea of brand-less corner store competitors throughout South Los Angeles. Specifically, he described his desire to create the "Latino 7-Eleven," referencing the success of the global convenience store chain. He liked the recognizable power of the 7-Eleven brand, as well as its professional retail standards, but knew that 7-Eleven was not targeting a Latino audience. The rebrand's graphic identity actually preceded and inspired the name Alba Snacks \& Services. The graphics sought to tap into a more "authentic" identity and style around Garcia's Latino heritage and social practices around snacking, while appealing to a more youthful audience (see Banet-Weiser 2012; Davila 2002; Hill 1988). ${ }^{6}$ Graphic identity development worked in a circular fashion, citing various reference points and combining influences in an attempt to create unforeseeable and imaginative solutions (see Agha 2015; Nakassis 2012; Vann 2006). The process began with an examination of well-known traditional Guatemalan textiles, as the lead graphic designer felt that the textiles were an obvious reference point because of Garcia's Guatemalan heritage, however cliché. Further, the "zig-zag" pattern of these traditional Guatemalan textiles resonated with the concept of snacking, because the designers read the snack as a similarly temporary form, an interval between more permanent shapes and a quick movement from one direction to another. The traditional zig-zag pattern was further developed through the lens of the Italian fashion brand Missoni, which itself cited Guatemalan textiles as an inspiration. Missoni's appropriation reinforced the design team's sense that this brand identity could be youthful and fashionable, with a touch of the authentic. Designers tried not to overwork traditional textile motifs, instead using the pattern as a more subtle touch point. They hoped to capture a reference to the authentic, without actually trying to be an authentic Guatemalan brand. They reasoned that striving for authenticity would be perceived as disingenuous because Central American food products represented just a small part of the overall product selection and the business did not actually originate in Guatemala.

The naming process began on the heels of developing the new graphic identity. "Alba" is Garcia's wife's name. As a word, it is snack-like: short, memorable, clear, and could be easily pronounced by both native English or Spanish speakers. In addition, the rebrand team reasoned that because Alba, the person, was from Guatemala and named by Guatemalan parents, it had a satisfactory degree of authenticity. Similar to the way Guatemalan textiles were cited in the brand identity without embracing authenticity, the team liked that "Alba" again cited Guatemala in an

\footnotetext{
${ }^{6}$ We understand that the concept of "authentic" cultural identity in this way is a social construction. That said, drawing on local understandings of "authenticity" and identity are important tools in establishing a retail brand. See also BanetWeiser (2012).
} 
indirect manner. The rebrand team consciously sought to engage younger Latinos with the brand, seeking a respectable and fashion-forward, hip destination. This was a deliberate attempt to invoke Latinidad to create a feeling of comfort and trust in Garcia's clientele (see Craciun 2012; Davila 2002). Garcia whole-heartedly approved the name, expressing delight in the sound of his wife's name, and his family embraced the brand. The title "Snacks and Services" was appended to the Alba name in order to clarify the brand's offering.

The process of branding Alba illuminates how retail brands can negotiate relationships between cultural traditions, community institutions and capitalist projects, including vast selections of products, in order to create potentially novel, yet familiar brand imaginaries. Different brand forms and brand strategies pursue different pathways toward these immersive imaginary spaces. The reference point for a product brand is often the maker, source or "birth" of the commodity (Coombe 1996), and the product brand's trustworthiness and perceived value often centers on imagined or fictive creative acts, whether a Louis Vuitton handbag stitched together by a craftsman or an Apple iPhone designed in California. The retail brand, on the other hand, often revolves around the concept of an imagined editor or curator, whether personified by a name such as Alba or an organization such as Walmart, who mixes and matches products and selects product brands from a wide range of possibilities, bringing them all together in one physical space. In this sense, retail brands like Alba may seek to reclaim the role of a semisanctioned intermediary in the commodity supply chain and larger cultural imaginary of the branding world.

As Robert Moore (2003) has demonstrated, the value of brands is always vulnerable, not only to cultural and market forces, but also to shifting legal standards and regimes. The Alba name was not copyrighted or protected legally. In fact, other corner store owners were invited to visit the store, and Garcia and Powell on various occasions explained the details of how the store rebrand worked to various audiences. The legal vulnerability of the Alba brand is certainly a function of limited budget, and perhaps if the store grows into a chain, future investors may secure intellectual property rights. But this legal vulnerability also highlights a peculiarity and slipperiness around mediation brands, because while the name Alba could certainly be trademarked, its distinctiveness is not its name or product. What is being branded is a practice or process of making sense, putting the object world into context and ultimately, making decisions. To our knowledge, retailers have not filed lawsuits claiming curation plagiarism (though there are certainly instances of trademark infringement around the naming of retail brands and their branded private label products). This speaks to the mundane yet powerful role of retailers, as mediation brands are not consumed per se, but they consume alongside the consumer. In the case of retailers, the 
practice of shopping in a specific manner is branded. And an examination of the production of retail brands, especially through curation, can help illuminate the ways that shopping is influenced.

\section{Conclusions}

In this article, we show that the retail brand is useful for exploring some ways brands work, in business and beyond. Alba is not merely providing access to commodities and meeting needs, but also has the potential to shape behavior and produce culture. The larger project undertaken by brand managers and strategists at all levels of public and private institutions, big and small, is to discover new ways to deliver distinctive and memorable proprietary experiences, as well as encouraging certain types of behaviors or ways of thinking and making sense of the world. Therefore, the social role of brands must be continually interrogated and reevaluated in relation to everyday consumption practices. This constantly shifting terrain may frustrate the critique of branding and its accompanying capitalist logic, because looking at branding as a cultural project means this formula may be appropriated in a variety of ways and for a variety of different purposes.

Drawing on insights from the Alba rebrand, we have demonstrated how retail brands function today as cultural mediators. This is perhaps increasingly important and valuable for people in a context of greater flows of information and unregulated exposure to product brands. A retail brand, even a small corner store in South Los Angeles, has the potential to influence how people shop for food and how their consumer desires and habits around food consumption develop. Other deliberately designed and immersive environments may have a similar capacity to impact a wide variety of different registers, including community development, business development, and public health. The immersive and embodied retail space makes the communication of brand there unavoidable; though often in subtle ways that go unnoticed.

Finally, the Alba rebrand demonstrates the importance of considering retail brands when thinking through shifting practices of consumption across the globe. The way in which a retail space is crafted establishes clear links between brand strategies and cultural production to build the identity of a space that people interact with in particular ways, which may be telling of their own individual or collective identities. This work further exposes the tension between local desires and global forces in how retail brands function.

In closing, the current article has focused on the conversion and production of a new retail brand, which obviously raises the question and problem of shopper reception. A subsequent article by the authors or others may seek to fully address this question of reception, though it should be noted that the production of this brand and its mediation 
function cannot be extricated from the practice or ritual of shopping or consumption. Preliminary findings nonetheless suggest that the Alba store saw an uptick in sales and shopper traffic, as well as a heightened positive reputation in the local community.

\section{References}

Agha, A. 2015 "Tropes of Branding in Forms of Life." Signs and Society 3: 174-194. https://doi.org/10.1086/679004

Allison, A. 2009 "The Cool Brand, Affective Activism and Japanese Youth." Theory Culture Society 26: 89-111. https://doi.org/10.1177/0263276409103118

Appel, H. 2015 “On Simultaneity." Theorizing the Contemporary, Cultural Anthropology website, March 30, 2015.

http://www.culanth.org/fieldsights/658-on-simultaneity

Arvidsson, A. 2006 Brands: Meaning and Value in Media Culture. New York: Routledge.

Banet-Weiser, S. 2012 Authentic: The Politics of Ambivalence in a Brand Culture. New York: New York University Press.

Bear, L., K. Ho, A. Tsing, and S. Yanagisako. 2015 "Gens: A Feminist Manifesto for the Study of Capitalism." Theorizing the Contemporary, Cultural Anthropology website, March 30, 2015.

http://www.culanth.org/fieldsights/652-gens-a-feminist-manifesto-forthe-study-of-capitalism

Boellstorff, T. 2003 "Dubbing Culture: Indonesian Gay and Lesbi Subjectivities and Ethnography in an Already Globalized World." American Ethnologist 30(2): 225-242. https://doi.org/10.1525/ae.2003.30.2.225

Bourdieu, P. 1984 Distinction: A Social Critique of the Judgement of Taste. Trans. Richard Nice. Cambridge: Harvard University Press.

Bratich, J. 2011 “User-Generated Discontent.” Cultural Studies 25 (4-5): 621-640. https://doi.org/10.1080/09502386.2011.600552

Caldwell, M. 2004 Not by Bread Alone: Social Support in the New Russia. Berkeley: University of California Press.

Cayla, J. and G.M. Eckhardt. 2008 "Asian Brands and the Shaping of a Transnational Imagined Community," Journal of Consumer Research, 35 (August), 216-30. https://doi.org/10.1086/587629

Craciun, M. 2012 "Rethinking Fakes, Authenticating Selves." Journal of the Royal Anthropological Institute 18: 846-63.

https://doi.org/10.1111/j.1467-9655.2012.01795.x 
Coombe, R. 1998 The Cultural Life of Intellectual Properties: Authorship, Appropriation and the Law. Durham, NC: Duke University Press. https://doi.org/10.1215/9780822382492

Davila, A. 2002 "Talking Back: Spanish Media and U.S. Latinidad." In Latino/a Popular Culture, eds. Michelle Habell-Pallan and Mary Romero. New York, NY: New York University Press: 25-37.

Dent, A. S. 2012 "Piracy, Circulatory Legitimacy, and Neoliberal Subjectivity in Brazil." Cultural Anthropology 27 (1): 28-49. https://doi.org/10.1111/j.1548-1360.2012.01125.x

Diamond, N., J.F. Sherry Jr., A.M. Muniz Jr., M.A. McGrath, R.V. Kozinets, and S. Borghini. 2009 "American Girl and the Brand Gestalt: Closing the Loop on Sociocultural Branding Research," Journal of Marketing, 73 (May): 118-34. https://doi.org/10.1509/jmkg.73.3.118

Fortun, K. 2012 "Ethnography in Late Industrialism." Cultural Anthropology 27 (3): 446-464. https://doi.org/10.1111/j.15481360.2012.01153.x

Foster, R. 2007 "The Work of the New Economy: Consumers, Brands, and Value Creation." Cultural Anthropology 22 (4): 707-731. https://doi.org/10.1525/can.2007.22.4.707

Garth, H. and M. Powell. 2013 "A Collaborative Approach To Studying Food Justice In Los Angeles." Anthropology News 54(10).

Glaser, M. 1985 “I Listen to the Market." In On Signs, ed. Marshall Blonsky. Baltimore, MD: The Johns Hopkins University Press: 467-474.

Graan, A. 2013 "Counterfeiting the Nation? Skopje 2014 and the Politics of Nation Branding in Macedonia." Cultural Anthropology 28 (1): 161-179. https://doi.org/10.1111/j.1548-1360.2012.01179.x

Hill, J. H. 1998 “Language, Race, and White Public Space.” American Anthropologist 100 (3): 680-689. https://doi.org/10.1525/aa.1998.100.3.680

Holt, D. 2004 How Brands Become Icons: The Principles of Cultural Branding. Cambridge, MA: Harvard Business School Press.

Holt, D. 2012 Cultural Strategy: Using Innovative Ideologies to Create Breakthrough Brands. Oxford: Oxford University Press.

Joy, A. and Eric P. H. Li 2012 "Studying Consumption Behaviour through Multiple Lenses: An Overview of Consumer Culture Theory." Journal of Business Anthropology 1 (1): 141-173.

Jung, Y. and A. Newman. 2014 "An Edible Moral Economy in the Motor City: Food Politics and Urban Governance in Detroit." Gastronomica: The Journal of Critical Food Studies, 14(1): 23-32. https://doi.org/10.1525/gfc.2014.14.1.23 
Kelley, R.D.G. 1997 Yo Mama's Disfunktional: Fighting the Culture Wars in Urban America. Boston: Beacon Press.

Klumbyte, N. 2010 "The Soviet Sausage Renaissance." American Anthropologist, 112 (1): 22-37. https://doi.org/10.1111/j.15481433.2009.01194.x

Lury, C. 2004 Brands: The Logos of the Global Economy. New York: Routledge.

Lury, C. 2010 Consumer Culture (2nd Edition). New Brunswick NJ: Rutgers University Press.

Luvaas, B. 2010 "Designer Vandalism: Indonesian Indie Fashion and the Cultural Practice of Cut 'n' Paste." Visual Anthropology Review 26(1):1-16. https://doi.org/10.1111/j.1548-7458.2010.01043.x

Luvaas, B. 2013 "Material Interventions: Indonesian DIY Fashion and the Regime of the Global Brand." Cultural Anthropology 28 (1): 127-143. https://doi.org/10.1111/j.1548-1360.2012.01177.x

Manning, P. 2010 "The Semiotics of Brand." Annual Review of Anthropology 39: 33-49. https://doi.org/10.1146/annurev.anthro.012809.104939

Manning, P. and P. Uplisashvili 2007 “'Our Beer': Ethnographic Brands in Postsocialist Georgia." American Anthropologist 109 (4): 626-641. https://doi.org/10.1525/aa.2007.109.4.626

Mazzarella, W. 2003 Shoveling Smoke: Advertising and Globalization in Contemporary India. Durham, NC: Duke University Press. https://doi.org/10.1215/9780822385196

Miller, D. 1998 A Theory of Shopping. Ithaca NY: Cornell University Press. Miller, D. 2001 The Dialectics of Shopping. Chicago: University of Chicago Press.

Moore, R. E. 2003 “From Genericide to Viral Marketing: On 'Brand.” Language \& Communication 23: 331-357. https://doi.org/10.1016/s0271-5309(03)00017-x

Murphy, K. 2013 "A Cultural Geometry: Designing Political Things in Sweden." American Ethnologist 40 (1): 118-131. https://doi.org/10.1111/amet.12009

Nakassis, C. V. 2012 "Counterfeiting What? Aesthetics of Brandedness and the Brand in Tamil Nadu, India." Anthropological Quarterly 85(3): 701722. https://doi.org/10.1353/anq.2012.0046

Nakassis, C. V. 2013 "Brands and their Surfeits." Cultural Anthropology 28 (1): 111-126. https://doi.org/10.1111/j.1548-1360.2012.01176.x

0’Connor, K. 2003 “Communicative Practice, Cultural Production and Situated Learning: Constructing and Contesting Identities of Expertise in a 
Heterogeneous Learning Context." In Linguistic Anthropology of Education, edited by Stanton Wortham and Betsy Rymes, 61-91. Westport, CT: Praeger.

Pine, J. and J. Gilmore. 1999 The Experience Economy. Boston: Harvard Business School Press.

Redmond, S. and D. Sojoyner. 2015 "Keywords in Black Protest: A(n Anti-) Vocabulary." Truth Out website, May 29, 2015. http://www.truthout.org/opinion/item/31051-keywords-in-black-protest-a-n-antivocabulary

Shankar, S. 2012 "Creating Model Consumers: Producing Ethnicity, Race, and Class in Asian American Advertising." American Ethnologist 39 (3): 578-591. HTTPS://DOI.ORG/10.1111/J.1548-1425.2012.01382.X

Taylor, K. 2016 From \#BlackLivesMatter to Black Liberation. Chicago: Haymarket Books.

Thomas, K. 2013 "Brand 'Piracy' and Postwar Statecraft in Guatemala." Cultural Anthropology 28(1): 144-160. https://doi.org/10.1111/j.15481360.2012.01178.x

Thomas, K. 2014 "Corporations and Communities in Highland Guatemala." PoLAR: Political and Legal Anthropology Review 37(2): 231245. https://doi.org/10.1111/plar.12072

Vann, E. 2006 "The Limits of Authenticity in Vietnamese Consumer Markets." American Anthropologist 108(2): 286-296. https://doi.org/10.1525/aa.2006.108.2.286

Weiss, B. 2012 "Configuring the Authentic Value of Real Food: Farm-toFork, Snout-to-Tail, and Local Food Movements." American Ethnologist 39 (3): 614-626. https://doi.org/10.1111/j.1548-1425.2012.01384.x

\section{Acknowledgements}

We are grateful to insights on earlier versions of this article from Dominic Boyer, Lee Cabatingan, James Faubion, Angela Fillingim, Cymene Howe, Chris Kelty, Leo Chavez, Brent Luvaas, George Marcus, Timothy de Waal Malefyt, and Keith Murphy. A version of this article was presented at the 2016 AAA panel "Para-ethnographies of Branding and Design." We thank the audience members and participants Curt Gambetta and Stephanie Sadre-Orafai. We also thank our anonymous reviewers, and JBA editors Brian Moeran and Greg Urban. Special thanks go to Nelson Garcia, Clare Fox, Rudy Espinoza, Christel Miller and Natilee Harren. 
Hanna Garth is a sociocultural and medical anthropologist interested in questions of inequality and structural violence. She studies food access in Cuba and food justice in Los Angeles. She is an Assistant Professor of Anthropology at the University of California San Diego.

Michael G. Powell is a sociocultural anthropologist who works for Shook Kelley, a strategy and design firm in Los Angeles. Following doctorate work in anthropology at Rice University, he has worked on consulting projects in a diverse range of industries, including retail, financial services, automotive, higher education, and home developments. 